\title{
The Formation of Green Buying Strategy on the Scope of Consumer Decision Making Behavior
}

\author{
M. Yaman Öztek, Galatasaray University, Istanbul, Turkey, moztek@gsu.edu.tr \\ Özgür Çengel, Istanbul Commerce University, Istanbul, Turkey, ocengel@ticaret.edu.tr
}

\begin{abstract}
As the natural resources are becoming scarce and the concept of environmentalism is on the rise, green buying behavior has increased the attention of many academicians and practitioners as an emerging strategy. In literature, green buying is also titled as environmental consumerism and defined as "purchasing and consuming products that are benign toward the environment". Under this approach, such literature also brings along a new terminology called "environmentally conscious behavior". There is, on the other side, a huge irony behind the advancement of technology in product innovation. Even though, technology oriented goods offer a variety of benefits to consumers, they also create pollution to the environment. Thus, there is a growing number of consumers that seek environment-friendly goods and services. In this globe, the major goal of this study is to understand consumer's knowledge and perception regarding the consumption of environmental goods. Furthermore, the study also aims to constitute green buying habits, overall attitudes towards environmentalism, and factors that affect the environmental conscious purchases. With the aid of randomly selected respondents, a written survey will be analyzed by multiple regression as a specific goal to measure consumer perception and green buying behavior variables along with demographical factors.
\end{abstract}

Key Word Green buying, environmental consciousness, multiple regression 


\section{INTRODUCTION}

In the consumer decision making behavior, there are many terms to introduce. Especially in the era of high global competition, such concerns as environmentalism and green buying have been critical issues to consider in the overall process of conducting business at both national and international levels. In this globe, this focus of concern has been an emerging strategy and a factor of necessity for business practices. In this sense, environmental conscious behavior is a new consumer behavior trend that is becoming to be wide-spread in the era of changes in the concept of consumer behavior. Besides, there also are many terms of discussion on the topics of technology and product innovation which are cited to create pollution to the environment. So, it is crucial to understand and analyze the consumer's perception in the focus of environmental goods consumption. In addition, if a good amount of time and effort can be spent on the main discussion of green buying habits, attitudes towards the concept and implementation, and factors that are thought of influencing the purchases of environmental conscious goods and services, then there may be a room for effective strategy formation on the grounds of selecting the target market and meeting the needs of such customers.

\section{LITERATURE REVIEW}

Environmentalism is directly related with the social and psychographic issues regarding customers and from such attempts, environmental marketing has been prospered [1]. Among the many scales that have been generated to analyze the environmentalism, list of values scale (LOV Scale) has been used in many academic papers [2]. In literature, there is a good number of papers on the direction of ecologically concerned customers [3] and such target market plays a dominant role in the strategy formation of green buying attempts. In some studies on the topic, demographic and social factors have been taken into consideration for effective for strategy formation. Meneses and Palacio put for the distinction of ecologic concern in their studies[4]. In the literature of green marketing, environmental knowledge is being explained in terms of ecoliteracy and Laroche, at this point clarifies that the knowledge of individuals about the environmental factors plays a determining role in an attitude towars 
being environment-friendly [5]. Cheah and Phau state that there are several indicators of green buying strategy. These are listed as ecoliteracy, interpersonal influence, value orientation, and perceived product necessity [6]. Besides, several theories have been implemented to the green buying strategy formation. Among these, the major ones are social cognitive theory, theory of reasoned action, and self image congruity theory [7]. The basic assumption in all theories is that social and environmental factors are directly associated with the green buying strategy in the context of consumer decision making behavior.

Another theory by Salimath and Jones states that population ecology theory has a good ground in establishing a green buying strategy [8]. In this sense, the authors imply that population ecology and sustainability are the two primary concern of strategy generation. Especially, from a sustainability point of view, such theory has a great implication in the points of environmentalism and environment conscious behavior.

\section{THE FORMATION OF GREEN SUPPLY CHAINS AND ENVIRONMENT CONSCIOUSNESS}

Many research in the related field state that environmental consciousness and green supply chains should be considered under the notion of green buying strategy, because the process should start from greening the raw material as well. In this sense, there are a good number of papers that deal with greening and leaning the supply chains to meet this goal. Among many papers, Mollenkopf, Stolze, Tate, and Ueltschy state that green, lean, and global supply chains are inter-related. The authors state that the globalization of supply chains is supported by offshoring of production facilities, inventories, suppliers, and customers. Thus, in greening the supply chains, differences in economies, infrastructures, cultures, and politics are cited to play a dominant role [9]. In this perspective, Corbett and Klassen state that certain issues such as waste reduction, elimination of non value added activities in the term of excess time, labor, equipment and so forth should be minimized and optimized as a goal to lean the operational process of supply chain, thereby helping the overall activities in the greening focus[10]. It is noted that green buying strategy is influenced by several factors namely regulations, trade barriers, and government intervention [11]. 


\section{INNOVATION MANAGEMENT AND GREEN BUYING STRATEGY}

Innovation management is a key driving force behind the fact of green buying strategy and it is noted in many papers that there is a direct correlation between the two strategies. Wolfe states that there are three schools of innovation on the concept of logistics activities. These are listed as process theory, systemic innovativeness diffusion of innovation, and network innovation [12]. In this sense, innovative approach should be conducted to the strategy of green buying and effective strategies should be generated based on the target market.

In this context, Lee establishes three steps in the green marketing strategy. These are during the years of 1980's, 1990's, and 2000's respectively. In 2000's, there is the maximum level of concern towards environmentalism and there are much higher audit issues of environmentalism and related production activities [13]. In this consideration, innovative products are enforced to be environment friendly, thereby preventing the pollution of the environment. In the green marketing theory of debate, green marketing tools, perception eco-labeling, perception of eco-brand, environmental advertisements, and consumer's actual purchase behavior are the primary issues of study [14]. Barber states that when placing green products in the right market position, it is of crucial concern to identify the environmental consumers. Barber, at this point, classifies environmentally conscious consumers and implies that segmentation based upon the attitudes, values, knowledge, levels of environmental purchase behavior, and demographic concerns should be conducted [15]. In the study by Murphy and Poist, there are twelve measures to analyze in the concept of green buying and environmentalism. These are reducing consumption, reusing materials, recycling, redesign of logistics system, reject suppliers who lack environmental concerns, increasing education and training, encouraging government involvement, publicizing environmental efforts, promoting industry cooperation, conducting audits, using third parties, hiring more environmental conscious personnel[16]. $\mathrm{Wu}$ and Dunn clarifies that in environmental friendly chain, there are six processes. These are raw material acquisition, inbound logistics, transformation, outbound logistics, marketing, and after sales [17]. 


\section{METHOD}

\section{Sample}

The research sample is composed of 126 subjects. Socio-demographic information (gender, age, income, education and marital status information) is summarized in Table 1.

Table 1 : Socio-Demographic Information

\begin{tabular}{lccc}
\hline Variable & Group & $\mathrm{N}$ & $\%$ \\
\hline Gender & Female & 54 & 42,9 \\
& Male & 72 & 57,1 \\
Education & $>11$ years & 91 & 72,2 \\
& $\leq 11$ years & 35 & 27,8 \\
Marital Status & Unmarried & 60 & 47,6 \\
& Married & 66 & 52,4 \\
Age & $<21$ years & 5 & 4,0 \\
& $21-40$ years & 104 & 82,5 \\
\multirow{2}{*}{ Income } & $>40$ years & 17 & 13,5 \\
& $<1001 \mathrm{TL}$ & 20 & 15,9 \\
& $1001-5000 \mathrm{TL}$ & 93 & 73,8 \\
& $>5000 \mathrm{TL}$ & 13 & 10,3 \\
\hline
\end{tabular}

\section{Instrument}

The research sample is given a survey form prepared by the researcher. The survey form is composed of 6 items that questions the subjects concerning their attitudes about environmental conscious purchase. In Table 2, a copy of the survey form is provided.

TABLE 2: Survey Form

\begin{tabular}{|c|c|c|c|c|c|c|}
\hline \multicolumn{2}{|c|}{ Questions } & \multirow{2}{*}{$\begin{array}{l}0 \\
0 \\
1\end{array}$} & \multirow{2}{*}{$\frac{\stackrel{n}{N}}{20}$} & \multirow{2}{*}{$\begin{array}{l}\text { 우 } \\
0^{\circ} \\
3\end{array}$} & \multirow{2}{*}{$\begin{array}{l}\frac{10}{2} \\
\frac{0}{0} \\
4\end{array}$} & \multirow{2}{*}{$\begin{array}{l}\stackrel{8}{\circ} \\
\text { 웅 } \\
5\end{array}$} \\
\hline 1 & Çevre kirliliği ve çevre sorunlarına ne kadar duyarlı birisiniz? & & & & & \\
\hline 2 & $\begin{array}{l}\text { Çevreye duyarlı şekilde sağlanan ürünlere/hizmetlere ne kadar önem } \\
\text { veriyorsunuz? }\end{array}$ & 1 & 2 & 3 & 4 & 5 \\
\hline 3 & $\begin{array}{l}\text { Çevreye duyarlı alışveriş yapmanızda, ürünün/hizmetin fiyatının } \\
\text { etkisi ne kadardır? }\end{array}$ & 1 & 2 & 3 & 4 & 5 \\
\hline 4 & $\begin{array}{l}\text { Çevreye duyarlı alışveriş yapmanızda, ürünün/hizmetin niteliklerinin } \\
\text { etkisi ne kadardır? }\end{array}$ & 1 & 2 & 3 & 4 & 5 \\
\hline 5 & $\begin{array}{l}\text { Çevreye duyarlı alışveriş yapmanızda, ürünü/hizmeti üreten veya } \\
\text { sağlayan firmanın çevresel konulara ilişkin yaklaşımının etkisi ne } \\
\text { kadardır? }\end{array}$ & 1 & 2 & 3 & 4 & 5 \\
\hline 6 & $\begin{array}{l}\text { Çevreye duyarlı alışveriş yapmanızda, medyanın, aile çevrenizin veya } \\
\text { toplumsal çevrenizin etkisi ne kadardır? }\end{array}$ & 1 & 2 & 3 & 4 & 5 \\
\hline
\end{tabular}




\section{Data Analysis}

The data collected from the research sample is analyzed using SPSS statistical analysis program. The data analysis is done in two steps. In the first step the descriptive statistics for the items of the survey form are calculated. In the second step group comparison and correlation analysis according to the socio-demographic variables are done.

\section{RESULTS}

The descriptive statistics for each of the survey question is given in Table 3. It is seen that in question 1 (Çevre kirliliği ve çevre sorunlarına ne kadar duyarlı birisiniz?) 82,6\% of the subjects, in question 2 (Çevreye duyarlı şekilde sağlanan ürünlere/hizmetlere ne kadar önem veriyorsunuz?) $73,0 \%$ of the subjects, in question 3 (Çevreye duyarlı alışveriş yapmanızda, ürünün/hizmetin fiyatının etkisi ne kadardır?) $61,9 \%$ of the subjects, in question 4 (Çevreye duyarlı alışveriş yapmanızda, ürünün/hizmetin niteliklerinin etkisi ne kadardır?) $73,0 \%$ of the subjects, in question 5 (Çevreye duyarlı alışveriş yapmanızda, ürünü/hizmeti üreten veya sağlayan firmanın çevresel konulara ilişkin yaklaşımının etkisi ne kadardır?) $67,5 \%$ of the subjects, and in question 6 (Çevreye duyarlı alışveriş yapmanızda, medyanın, aile çevrenizin veya toplumsal çevrenizin etkisi ne kadardır?) 58,7\% of the subjects answered the questions with a very positive attitude ( $75 \%$ and $100 \%$ agreement).

Table 3: Descriptive Statistics for the Survey Questions

\begin{tabular}{lcccccccccccc}
\hline \multirow{2}{*}{ Question } & \multicolumn{2}{c}{$0 \%$} & \multicolumn{2}{c}{$25 \%$} & \multicolumn{2}{c}{$50 \%$} & \multicolumn{2}{c}{$75 \%$} & \multicolumn{2}{c}{$100 \%$} & \multirow{2}{*}{ M } & SD \\
& $\mathrm{N}$ & $\%$ & $\mathrm{~N}$ & $\%$ & $\mathrm{~N}$ & $\%$ & $\mathrm{~N}$ & $\%$ & $\mathrm{~N}$ & $\%$ & & \\
\hline Q1 & 0 & $0,0 \%$ & 5 & $4,0 \%$ & 17 & $13,5 \%$ & 70 & $55,6 \%$ & 34 & $27,0 \%$ & 4,06 & 0,75 \\
Q2 & 0 & $0,0 \%$ & 5 & $4,0 \%$ & 29 & $23,0 \%$ & 62 & $49,2 \%$ & 30 & $23,8 \%$ & 3,93 & 0,79 \\
Q3 & 2 & $1,6 \%$ & 8 & $6,3 \%$ & 38 & $30,2 \%$ & 54 & $42,9 \%$ & 24 & $19,0 \%$ & 3,71 & 0,90 \\
Q4 & 1 & $0,8 \%$ & 6 & $4,8 \%$ & 27 & $21,4 \%$ & 51 & $40,5 \%$ & 41 & $32,5 \%$ & 3,99 & 0,90 \\
Q5 & 1 & $0,8 \%$ & 11 & $8,7 \%$ & 29 & $23,0 \%$ & 58 & $46,0 \%$ & 27 & $21,4 \%$ & 3,79 & 0,91 \\
Q6 & 4 & $3,2 \%$ & 9 & $7,1 \%$ & 39 & $31,0 \%$ & 49 & $38,9 \%$ & 25 & $19,8 \%$ & 3,65 & 0,98 \\
\hline
\end{tabular}

In socio-demographic group comparisons gender, education and marital status groups are compared for each of the survey question. 
The t-test comparisons of the gender groups are given in Table 4. It is found that, except the question 1, in all of the questions the female group scored higher than the male group. The score differences between the female and male groups achieved statistical significance in question 3 (Çevreye duyarlı alışveriş yapmanızda, ürünün/hizmetin fiyatının etkisi ne kadardır?): $\mathrm{t}(124)=2.32$, $\mathrm{p}<0.05$; question 5 (Çevreye duyarlı alışveriş yapmanızda, ürünü/hizmeti üreten veya sağlayan firmanın çevresel konulara ilişkin yaklaşımının etkisi ne kadardır?): $\mathrm{t}(124)=3.20, \mathrm{p}<0.01$; and in question 6 (Çevreye duyarlı alışveriş yapmanızda, medyanın, aile çevrenizin veya toplumsal çevrenizin etkisi ne kadardır?): t $(124)=2.80$, $\mathrm{p}<0.01$.

Table 4: Comparison of Gender Groups

\begin{tabular}{lllllll}
\hline Question & Gender & $\mathrm{N}$ & $\mathrm{M}$ & $\mathrm{SD}$ & $\mathrm{t}_{(124)}$ & $\mathrm{p}$ \\
\hline \multirow{2}{*}{ Q1 } & Female & 54 & 3,98 & 0,81 & $-0,96$ & 0,340 \\
& Male & 72 & 4,11 & 0,70 & & \\
Q2 & Female & 54 & 3,98 & 0,81 & 0,65 & 0,518 \\
& Male & 72 & 3,89 & 0,78 & & \\
Q3 & Female & 54 & 3,93 & 0,91 & 2,32 & 0,022 \\
& Male & 72 & 3,56 & 0,87 & & \\
Q4 & Female & 54 & 4,13 & 0,93 & 1,50 & 0,137 \\
& Male & 72 & 3,89 & 0,87 & & \\
Q5 & Female & 54 & 4,07 & 0,89 & 3,20 & 0,002 \\
& Male & 72 & 3,57 & 0,87 & & \\
Q6 & Female & 54 & 3,93 & 0,93 & 2,80 & 0,006 \\
\hline
\end{tabular}

The t-test comparisons of the education groups are given in Table 5. It is found that, except the question 6 , in all of the questions $>11$ years group (the university group) scored higher than the $\leq 11$ years group (primary, secondary and high school group). However, in none of the questions the score differences between the $>11$ years and $\leq 11$ years groups achieved a statistically significance level. 
Table 5: Comparison of Education Groups

\begin{tabular}{lllllll}
\hline Question & Education & $\mathrm{N}$ & $\mathrm{M}$ & $\mathrm{SD}$ & $\mathrm{t}(124)$ & $\mathrm{p}$ \\
\hline Q1 & $>11$ years & 91 & 4,12 & 0,70 & 1,58 & 0,116 \\
& $\leq 11$ years & 35 & 3,89 & 0,87 & & \\
Q2 & $>11$ years & 91 & 3,95 & 0,75 & 0,38 & 0,708 \\
& $\leq 11$ years & 35 & 3,89 & 0,90 & & \\
Q3 & $>11$ years & 91 & 3,76 & 0,86 & 0,88 & 0,380 \\
& $\leq 11$ years & 35 & 3,60 & 1,01 & & \\
Q4 & $>11$ years & 91 & 4,00 & 0,87 & 0,16 & 0,874 \\
& $\leq 11$ years & 35 & 3,97 & 0,99 & & \\
Q5 & $>11$ years & 91 & 3,86 & 0,82 & 1,43 & 0,156 \\
& $\leq 11$ years & 35 & 3,60 & 1,09 & & \\
Q6 & $>11$ years & 91 & 3,63 & 0,96 & $-0,45$ & 0,655 \\
\hline
\end{tabular}

The t-test comparisons of the marital status groups are given in Table 6. It is found that in questions 2 and 5 the unmarried group scored higher than the married group, and in questions 1, 3, 4 and 6 the married group scored higher than the unmarried group. However, in none of the questions the score differences between the unmarried and married groups achieved a statistically significance level.

Table 6: Comparison of Marital Status Groups

\begin{tabular}{|c|c|c|c|c|c|c|}
\hline Question & $\begin{array}{l}\text { Marital } \\
\text { Status }\end{array}$ & $\mathrm{N}$ & M & SD & $t_{(124)}$ & $\mathrm{p}$ \\
\hline \multirow{2}{*}{ Q1 } & Unmarried & 60 & 4,03 & 0,78 & \multirow{2}{*}{$-0,32$} & \multirow{2}{*}{0,753} \\
\hline & Married & 66 & 4,08 & 0,73 & & \\
\hline \multirow{2}{*}{ Q2 } & Unmarried & 60 & 3,98 & 0,79 & \multirow{2}{*}{0,74} & \multirow{2}{*}{0,461} \\
\hline & Married & 66 & 3,88 & 0,80 & & \\
\hline \multirow{2}{*}{ Q3 } & Unmarried & 60 & 3,60 & 0,96 & \multirow{2}{*}{$-1,36$} & \multirow{2}{*}{0,176} \\
\hline & Married & 66 & 3,82 & 0,84 & & \\
\hline \multirow{2}{*}{ Q4 } & Unmarried & 60 & 3,95 & 1,00 & \multirow{2}{*}{$-0,50$} & \multirow{2}{*}{0,618} \\
\hline & Married & 66 & 4,03 & 0,80 & & \\
\hline \multirow{2}{*}{ Q5 } & Unmarried & 60 & 3,80 & 1,01 & \multirow{2}{*}{0,17} & \multirow{2}{*}{0,867} \\
\hline & Married & 66 & 3,77 & 0,82 & & \\
\hline \multirow{2}{*}{ Q6 } & Unmarried & 60 & 3,60 & 1,08 & \multirow{2}{*}{$-0,55$} & \multirow{2}{*}{0,582} \\
\hline & Married & 66 & 3,70 & 0,89 & & \\
\hline
\end{tabular}

The Spearman's rho correlations of the age level and income level with the survey questions are given in Table 7. According to the findings, there are positive correlations between the age level and all of the questions (except question 2, which shows a very low 
negative correlation). However, these positive correlations are very low and none of them achieved a statistically significant level.

In the correlations of the income level and survey questions, in questions 2, 4 and 6 there are negative correlations between the income level and the survey questions, and in questions 1, 3 and 5 there are positive correlations; however none of these negative and positive correlations achieves a statistically significant level.

\section{Table 7: Correlations of the Age Level and Income Level with the Survey Questions}

\begin{tabular}{lcccc}
\hline \multirow{2}{*}{ Question } & \multicolumn{2}{c}{ Age } & \multicolumn{2}{c}{ Income } \\
& Spearman's rho & $\mathrm{p}$ & Spearman's rho & $\mathrm{p}$ \\
\hline Q1 & 0,06 & 0,500 & 0,13 & 0,144 \\
Q2 & $-0,04$ & 0,685 & $-0,04$ & 0,695 \\
Q3 & 0,04 & 0,653 & 0,04 & 0,664 \\
Q4 & 0,09 & 0,326 & $-0,04$ & 0,661 \\
Q5 & 0,08 & 0,352 & 0,05 & 0,600 \\
Q6 & 0,06 & 0,509 & $-0,14$ & 0,115 \\
\hline
\end{tabular}

In sum, we can say that the socio-demographic profile: females, with university education have the highest positive attitude towards environmental purchasing behavior.

\section{CONCLUSION}

It is important to realize the importance of green buying strategy in many ways. As there is a high level of competition throughout the world as a result of globalization issues, there is a growing demand on the issues of environmentalism. In this sense, focus on environmentalism is a differentiating factor in the attempt of establishing a good portfolio of customers.

To meet such challenges, this paper focuses on the changing and emerging aspects of consumer decision making behavior and sets certain strategies in the scope of green buying strategy. This paper includes a research where a good amount of effort has been spent towards analyzing the key determinants of consumer decision making behavior and attitudes that derive such strategy. This research can be identified as a key for companies 
who aim to generate green buying strategy considering the local market needs and expectations. Thus, it is being noted in the research many times that social, demographic, and other factors play a determinant role in the value perception of local consumers within the market in terms of green buying and environment consciousness.

\section{REFERENCES}

[1] McCarty, J.A. and Shrum, L.G, 1994, "The Recycling of Solid Wastes: Personal Values, Value Orientations, and Attitudes about Recycling as Antecedents of Recycling Behavior", Journal of Business Research, vol:30, no:1, pp:53-62

[2] Kahle, L.R, 1996, "Social Values and Consumer Behavior: Research from the List of Values," Lawrence Erlbaum Publications, vol:8, NJ, pp: 135-150

[3] Roberts, J.A. and Bacon, D.R, 1997, “Exploring the Subtle Relationships between Environmental Concern and Ecologically Conscious Consumer Behavior, Journal of Business Research, vol:40, no:1, pp:79-89

[4] Meneses, G.D. and Palacio, A.B, 2006, "Different Kinds of Consumer Response to the Reward Recycling Technique: Similarities at the Desired Routine Level", Asia Pacific Journal of Marketing \& Logistics, vol:18, no:1, pp:43-60

[5] Laroche, M, 2001, "Targeting Consumers Who are Willing to Pay More for Environmentally Friendly Products", Journal of Consumer Marketing, vol:18, no:6, pp:503-520

[6] Cheah, I and Phau, I, 2007, "Attitudes Towards Environmentally Friendly Products: The Influence of Ecoliteracy, Interpersonal Influence and Value Orientation", Emerald Group Publishing, pp:1- 33

[7] Cheah, I and Phau, I, 2007, "Attitudes Towards Environmentally Friendly Products: The Influence of Ecoliteracy, Interpersonal Influence and Value Orientation", Emerald Group Publishing, pp:1- 33

[8] Salimath, M.S. and Jones R, 2011, "Population Ecology Theory: Implications for Sustainability", Management Decision, vol:49, no: 6, pp: 874-910

[9] Mollenkopf, D, Stolze, H, Tate, W.L, and Ueltschy, M, 2010, “Green, Lean, and Global Supply Chains", International Journal of Physical Distribution\&Logistics Management, vol: 40, no:2, pp: $14-41$

[10]Corbett, C.J. and Klasses, R.D, Extending the Horizons: Environmental Excellence as Key to Improving Operations, Manufacturing\&Service Operations Managemenr, vol:8, no:1, pp:522

[11] Mollenkopf, D, Stolze, H, Tate, W.L, and Ueltschy, M, 2010, “Green, Lean, and Global Supply Chains", International Journal of Physical Distribution\&Logistics Management, vol: 40, no:2, pp: $14-41$ 
[12] Wolfe, R.A, 1994," Organizational Innovation: Review, Critique, and Suggested Research Directions", Journal of Management Studies, vol:31, no:3, pp: 405-431

[13] Lee, K, 2008, “ Opportunities for Green Marketing : Young Consumers”, Marketing Intelligence\& Planning, vol: 26, no:6, pp: 573-586

[14] Rahbar, E and Wahid, N.A, 2011, “Investigation of Green Marketing Tool's Effect on Consumer's Purchase Behavior", Business Strategy Series, vol: 12, no: 2, pp: 73-83

[15] Barber, N, 2010, "Green Wine Packaging: Targeting Environmental Consumers", International Journal of Wine Business Research, vol:22, no:4, pp: 423-444

[16] Poist, R.F and Murphy, P.R, 2003, “Green Perspectives and Practices: Comparative Logistics Study", Supply Chain Management: An International Journal, vol:8, no:2, pp:122-131

[17] $\mathrm{Wu}, \mathrm{H} . J$ and Dunn, S.C, 1995, "Environmentally Responsible Logistics Systems", International Journal of Physical Distribution\&Logistics Management, vol:25, no:2, pp: 20-38 